\title{
Perspectives on the Transformation of Breslau into Wrocław, 1945-1948
}

Roman Panickar is a senior majoring in Economics and History. He is from Frederick, Maryland. This article was supervised by Professors Elizabeth MacGonagle and Nathan Wood.

\section{Introduction}

$\mathrm{T}$ The early stages during the transformation of Breslau into Wrocław were some of the most trying times that the European city has seen in its nearly thousand-year history. The Second World War left Europe devastated, and the Eastern and Western portions of the continent chose different paths towards recovery from the destructive war. The question of Poland's borders and leadership stood at the forefront of many post-war conversations between the Allies. The end of the Second World War brought up the question of whether or not to maintain Poland's territorial integrity: Where exactly should the borders be drawn? And what ethnic composition should a post-war Poland have? At the war's end, the Soviet government already had troops on the ground in Poland, because of this, Western allies such as Britain and the United States had little room to maneuver during negotiations. ${ }^{1}$ When the Soviets decided that they wanted to shift the entire country of Poland westward, the Western allies had little choice but to agree.

After negotiations, The USSR annexed most of what was Eastern Poland, and, in replacement, they gave Poland most of what had previously been Eastern Germany. ${ }^{2}$ The abrupt and hasty nature of the region's transfer from Germany to Poland sets the

${ }^{1}$ Admiral William D. Leahy, "Notes on the Yalta Conference", The Wisconsin Magazine of History 38, no. 2 (1954): 72, 112.

${ }^{2}$ See Image 1 in Appendix. Retrieved from United States Holocaust Memorial Museum. stage for the transformation of Breslau into Wrocław.

The early period in the new Western Poland was commonly referred to as the "Wild West" because of the massive upheavals that happened as the region changed hands. This turmoil enveloped most of the province of Silesia, which is where the city Breslau, now Wrocław, is located. The city will henceforth be referred to as "Wrocław" in this article. Silesia was and still is a center of industry, and its historical capital has always been Wrocław. Wrocław had not been Polish territory since roughly the $14^{\text {th }}$ century, so the reintroduction greatly surprised the Western Allies.

One great example of the change which occurred in this city is the Iglica, the spire that was placed in front of the Centennial Hall in Wrocław in 1948 by the Polish Communist Government in anticipation of the Exhibition of Recovered Territories. ${ }^{3}$ The Iglica is shaped like a tripod and was designed by Stanisław Hempel. It was originally 106 meters tall, and the designer indicated that the spire was meant to represent national unity built on the alliance of workers, peasants, and working intelligentsia. ${ }^{4}$ The Centennial Hall, the main structure standing behind the Iglica, was designed by German

\footnotetext{
${ }^{3}$ Thank you to Professor Nathan Wood, University of Kansas, for bringing this landmark and his original ideas about its symbolism to my attention.

4 "Iglica." Visit Wrocław, Oficjalny serwis turystyczny, https://visitWrocław.eu/miejsce/iglica, (October 15, 2019).
} 


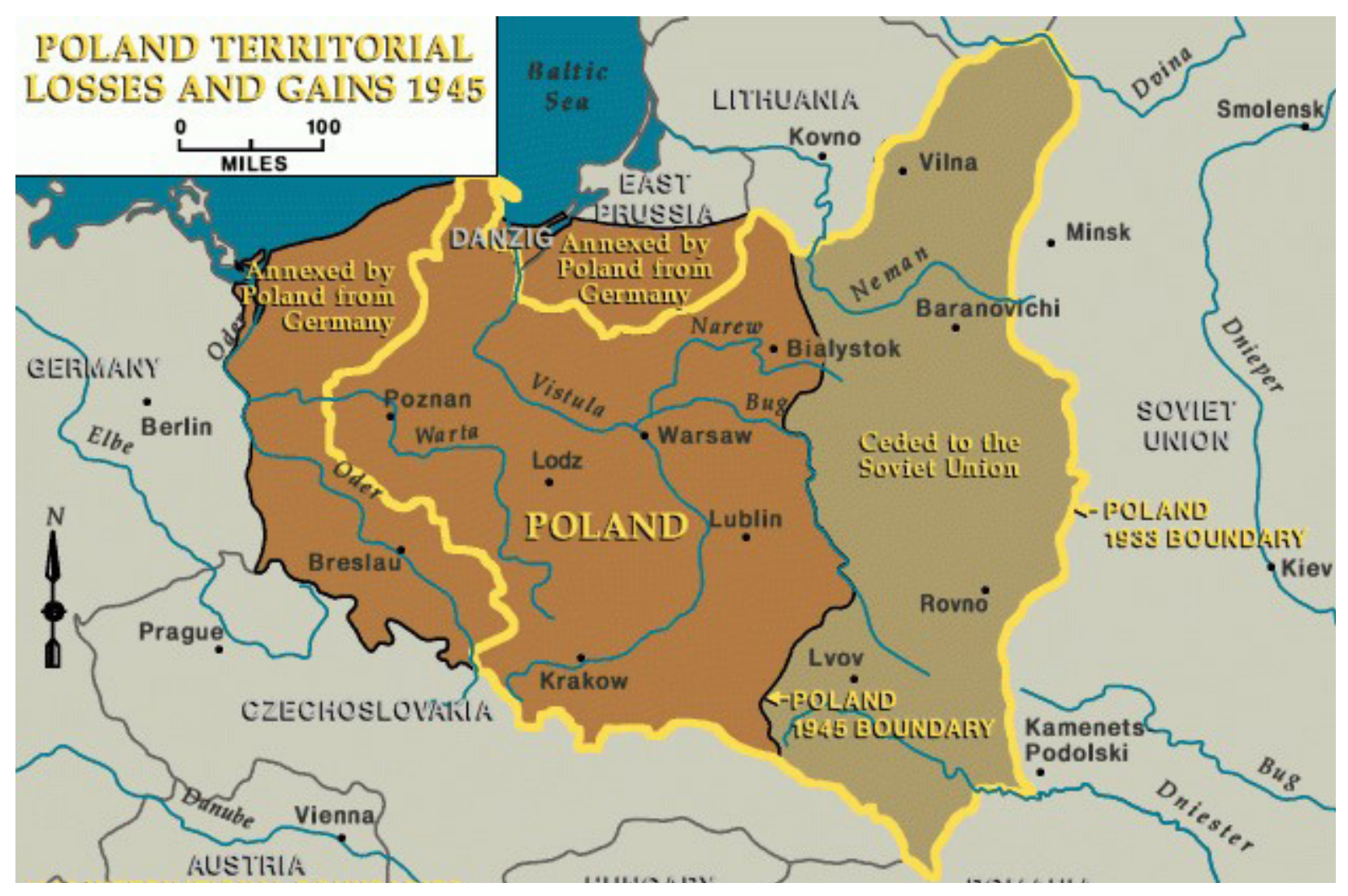

Poland Territorial Losses and Gains, 1945. Retrieved from the U.S. Holocaust Memorial Museum.

architect Max Berg and began construction in 1911 when Wrocław was still German territory. It was a massive architectural feat; at the time of its construction it stood as the largest reinforced concrete dome in the world, and it represented a state-of-the-art use of metal in structural consolidation. ${ }^{5}$

The Centennial Hall was meant to be used as an exhibition hall, place of assembly, and even as a sports venue. The German government put a lot of time, money, and effort into creating this display of German wealth, power, and architectural prowess. When Poland gained control of Wrocław, the presence of this landmark tapped into an un-

\footnotetext{
5 "Centennial Hall in Wrocław", UNESCO World Heritage Centre, https://whc.unesco.org/en/list/1165/, (October 15, 2019).
}

dercurrent of resentment towards Germans that resulted from the war. The Poles were in unfamiliar land and constantly surrounded by the remnants of its previous inhabitants, and, as such, they found ways to adapt the area to their needs, even if it meant putting up a monument of their own that did not match the architectural style or achieve any of the accomplishments of the German monument standing behind it. After the Iglica was put up, the magazine Przekrój claimed that the spire was "a symbol of industry in the West" and that it was "hard to find a better of symbol of change." ${ }^{\prime \prime}$ The visuals in an advertisement for a Ballet in 1948 fo-

\footnotetext{
${ }^{6}$ L. Wolanowski, "Iglica I Dobrzy Restauratorzy," Przekrój Issue 171, https://Przekrój.pl/en/archive/artykuly/7303?f=numer, (October 22, 2019), Par 1.
} 
cused on the newly built spire in front of the Centennial Hall without including the main structure behind it. ${ }^{7}$ The praise and attention that the spire received did not result from architectural or aesthetic accomplishments, rather, they were concerned with the spire as a symbol of making Wrocław Polish. The resentment behind the construction of the spire is the same motivation that guided both individual Poles and the Polish Government when incorporating Wrocław into Poland, and it is a large part of what caused the transfer to be bloody and chaotic.

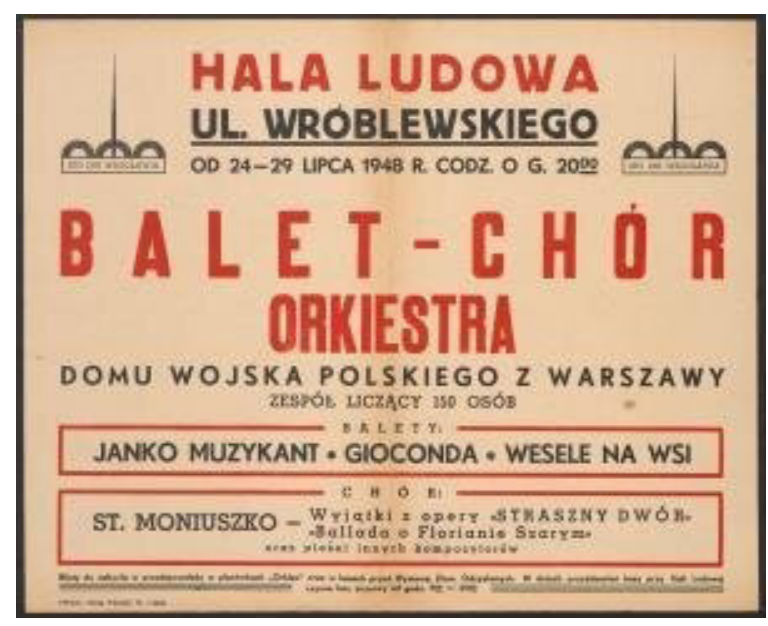

Balet, Chór, Orkiestra Domu Wojska Polskiego z Warszawy. Observe the emphasis on the spire in the top right and left corners of the advertisement.

Retrieved from Biblioteka Uniwersytecka we Wrocławiu.

The transformation of Breslau into Wrocław from 1945-1948 was one of the biggest turning points for the city in its history. The city was forced under Polish sovereignty despite having been German for hundreds of years prior, and this set the stage for it to be turned upside down. The

${ }^{7}$ Balet, Chór, Orkiestra Domu Wojska Polskiego z Warszawy. Photograph. Wrocław, 1948. See Image 2 in Appendix. Retrieved from Biblioteka Uniwersytecka we Wrocławiu. ethnic composition of the city was transformed thereby contributing to widespread social unrest and the civil and state administrations were ineffective and focused on the wrong problems. These two factors tended to combine and compound, and this led to a detrimental experience for most involved.

\section{Civilian Perspectives}

The civilian experience is complicated during the transformation of Breslau into Wrocław. This occurs for a multitude of reasons including post-war prejudices, desires for revenge, confusion caused by mass migration in and out of Wrocław, and the imposition of a communist society onto the "new" Polish city. The confluence of these factors eventually led to widespread social unrest.

One of the most important civilian aspects of this transformation is the mass migration of people both into and out of Wrocław that resulted after the Second World War. The ethnic composition of Wrocław changed drastically from 19451948. The goal of the Polish Communist government was to create an ethnically homogenous nation state, ${ }^{8}$ and, because of that, ethnic minorities in Polish territory, namely Germans, were removed. At the end of December 1945, “only 33,297 Poles were registered in Wrocław, compared to five times that number of Germans," and, "nine months later, the positions had been almost exactly reversed: 152,898 Poles against 28,274 Germans." "9 As Germans were ex-

\footnotetext{
${ }^{8}$ Joanna Talewicz-Kwiatkowska, "Persecution and Prejudice Against Roma People in Poland after World War II", The Polish Review 64, no. 2 (2019): 40.

${ }_{9}^{9}$ Norman Davies and Roger Moorhouse, Microcosm Portrait of a Central European City, (London: Pimlico, 2003), 419.
} 
pelled from the city, Poles arrived from all over Eastern Europe. They were relocated by force and often arrived from areas that "had been violently torn apart by military action, social engineering, successive genocides, ethnic cleansing, political purges, and plain banditry." The Soviet government used Catholicism and the ability to speak Polish as the twin criteria to decide who was Polish; this caused many mistakes when expelling people from the USSR and sending them to Poland. ${ }^{10}$ The Polish Government's plan to move Germans out and to settle Poles coming in was executed with extreme speed. A newspaper article from the Chicago Daily Tribune highlighted the fact that 3,000 Germans had left Poland in one day in 1946, and that the plan was to be rid of 1.5 million Germans in a span of five months. ${ }^{11}$ At the same time that this was happening, Poles and Soviet defined Poles were pouring into Poland. In 1946 alone, 130,000 people arrived in Wrocław. ${ }^{12}$

The new arrivals in Wrocław were not separated in any meaningful way, which only furthered social tensions in the recovering city. According to historian Gregor Thum, the chaos resulting from mass migration led to "professors living under the same roof as illiterates"13 as people were quickly and sloppily assigned abandoned homes to live in. Historian Padraic Kenney referred to Wrocław as "a camp filled with migrants

\footnotetext{
${ }^{10} \mathrm{Ibid}, 425-426$.

11 "3,000 Germans Leave Poland for Allie Zones," Chicago Daily Tribune (1923-1963), Feb 26, 1946.

${ }^{12}$ Alicja Maciaczyk, Statystyka Wrocławia w Latach 1945-199, (Wrocław: Urząd Statystyczny, 2000), 17.

${ }^{13}$ Gregor Thum, Uprooted: How Breslau Became Wroctaw during the Century of Expulsions, (Princeton: Princeton University Press, 2011), 178.
}

from all over Poland and Europe." ${ }^{14}$ The hastiness of the movement of people into and out of the city fostered widespread confusion which fomented social unrest during this period. Poles from all over Eastern Europe were moved to a city with which they were unfamiliar and lived with people coming from vastly different countries, ethnic backgrounds, economic backgrounds, and war experiences. The goal of this process was to create an ethnically homogenous Poland, but it soon became very clear that what had been created was a "conglomerate of different communities not conducive to the formation of broader allegiances of class or even of nation," 15 and that "there had never been an ethnically homogenous Poland." ${ }^{\prime 6}$ This was one of the first signs that this experiment may have led to what may be perceived as negative repercussions.

The Second World War left the nation in rubble, and the difficulties endured by Poles during the Holocaust and during combat took a lasting toll on the civilians of the country. As soon as the Poles had control of the city, German civilians that chose to stay were "subjected to the extremes of both deprivation and humiliation. Starving, sick, and stupefied, they bore the full brunt of the pent-up collective anger and contempt that Soviets and Poles alike had harboured." 17 According to Bishop Johannes Kaps, a German Bishop from the Archdiocese of Wrocław, Germans who remained in the city were "dreadfully maltreated by the Polish

\footnotetext{
${ }^{14}$ Ibid.

${ }^{15}$ Padraic Kenney, Rebuilding Poland Workers and Communists, 1945-195, (Ithaca, NY: Cornell Univ. Press, 2012), 138.

${ }^{16}$ Thum, Uprooted, 180.

${ }^{17}$ Davies \& Moorhouse, Microcosm, 408.
} 
militia." ${ }^{18}$ He claimed that Germans were often forced to work long hours for free, received less food than others, and that "no German's life was safe if he appeared on the street."19

The bloodthirsty treatment of German civilians remaining in Wrocław can be explained by exploring the Polish attitudes towards the war. The Polish people were subjected to a level of brutality and deprivation that took both a physical and mental toll on them during and after war. Poland was invaded by both the USSR and Nazi Germany at the beginning of the war and it had death camps set up and operated on its soil which exterminated millions of Jews and Poles. Warsaw, the capital, was razed to the ground by the Germans following a failed uprising, and Poland was then forced by the Soviets to adopt communism after the war. ${ }^{20}$ During the war, Poles were required to house German soldiers and were often times required to do forced, unpaid labor for the Germans. ${ }^{21}$ They too were slaughtered in the streets, discriminated against, oppressed, abused, and looted from. This does not justify Polish actions against Germans following the war, but the prevailing attitude towards remaining Germans was one of apathy at best and antipathy at worst.

Many Germans, including Bishop Kaps, the German bishop from the Archdiocese of Wrocław, still believed that the territory was

\footnotetext{
18 Ibid.

${ }^{19}$ Johannes Kaps, The Tragedy of Silesia 1945-46 ; a Documentary Account with a Special Survey of the Archdiocese of Breslau, (Munich: Christ Unterwegs, 1952), 137.

${ }^{20}$ Mitchell Orenstein, "Poland: From Tragedy to Triumph", Foreign Affairs 93, no. 1 (2014): 23.

${ }^{21}$ Henryk Kapturczak, Wspomnienia z Okresu Okupacji, (Poznań, 1947), Family Document.
}

rightfully German. ${ }^{22}$ Poles viewed this as further taunting after the atrocities committed against them during the war. The leading Polish opinion on the matter was that the Germans simply being allowed to leave was a preferable alternative to the treatment they received. Many Poles never had the option to leave and were killed or sent to concentration camps. ${ }^{23}$ Because of this, Poles had a strong desire for "a Polish historical landscape in the western territories purged of all German traces." 24

Another factor that contributed to the particularly brutal treatment of German civilians was what historians Davies and Moorhouse describe as a "palpable climate of impermanence" in Wrocław and the Western Territories as a whole. ${ }^{25}$ Poles were acutely aware of the fact that many Germans held attitudes similar to Bishop Kaps", and it led them to "never really settle into their new surroundings." ${ }^{26}$ Many of them longed for their familial homes in the East. This feeling only accelerated Polish mistreatment and persecution of remaining Germans. The longing for home and feeling of misplacement added to the already negative predisposition towards Germans due to the war. After having their homes torn apart by war, Poles were forced to move into the homes of the people they believed to have caused them this suffering. The Poles that now resided in Wrocław felt a need to assert themselves, and they likely expected that the Germans would soon return to reclaim the

\footnotetext{
${ }^{22}$ Kaps, Tragedy, 32-33.

${ }^{23}$ Anna Cienciala, "Poles and Jews Under German and Soviet Occupation, September 1, 1939 - June 22 1941", The Polish Review 46, no. 4 (2001): 393.

24 Thum, Uprooted, 250.

${ }^{25}$ Davis \& Moorhouse, Microcosm, 417.

${ }^{26}$ Thum, Uprooted, 186.
} 
territory and retaliate. Poles likely wanted to assert themselves as the new and rightful owners of the now Polish territory, and they likely believed they could discourage future retribution from the Germans through fear. ${ }^{27}$ Reconciliation with and apologies to Germans were not the goals of Poles moving into Wrocław at this time. Their methods were violent, but the motivations behind them stem from scars that resulted from the war.

The final factor that contributed to civilian chaos during the transformation of Breslau into Wrocław was the imposition of a communist society onto the newly Polish city. The Polish Communist government intended for Wrocław to be a part of "the Poland of the future, where social relations were reconstructed in a communist context." ${ }^{28}$ Many of the people who moved to Wrocław were "rural, young, poorly educated, and inexperienced," causing party membership to center around creating a worker's culture and community. ${ }^{29}$ Communism was unpopular with Poles, and "doubly so after Soviet misconduct in 1939-41,"30 but Wrocław presented a unique opportunity to create a communist society because Communism was seen as helping to bring order to the general chaos. It gave people who felt no sense of community or fellowship a common goal.

Civilians were encouraged to connect communism with Polish nationalism. A propaganda poster from the time shows a mile marker decorated with both traditional

\footnotetext{
${ }^{27}$ Arthur Westermayr, "The Psychology of Fear.," The Open Court Vol. 1915, no. 4 (1915): 250.

${ }^{28}$ Kenney, Rebuilding, 136.

${ }^{29}$ Ibid, 173.

${ }^{30}$ Davies \& Moorhouse, Microcosm, 411.
}

Polish symbols and various communist symbols. ${ }^{31}$ It was intended to connect the idea of the land being rightfully Polish to the idea of Poland as a communist regime. Besides the Soviet requirements of speaking Polish and being Catholic, many of the new residents of the city did not have a lot in common and likely were not in favor of communism to begin with. The imposition of communism and the creation of a communist society where one had not previously existed likely only added to the social unrest of the city at the time. Most now had to adapt to a society being restructured around a Soviet economic scheme which was likely different from ones they had lived in previously. This only furthered the social tensions of the city at the time.

The civilian perspective on the transformation of Breslau into Wrocław can best be described as complicated and chaotic. Mass migration following the war completely redefined the ethnic composition of the city. It forcibly uprooted people from the East and dumped them into one central location while forcing them to coexist. Amidst these changes, Polish people were to adapt to a new communist society, to deal with leftover wartime history, and to hastily develop community in their new, assigned homes. These factors led to widespread social unrest, violence, the shared and intangible feeling of anxiety, a feeling of unbelonging, and a difficulty recovering from the experiences of war.

\footnotetext{
${ }^{31}$ Ulotka Propagandowa: Wystawa Ziem Odzyskanych. Photograph. Wrocław, 1948. See Image 3 in Appendix. Retrieved from Biblioteka Uniwersytecka we Wrocławiu.
} 


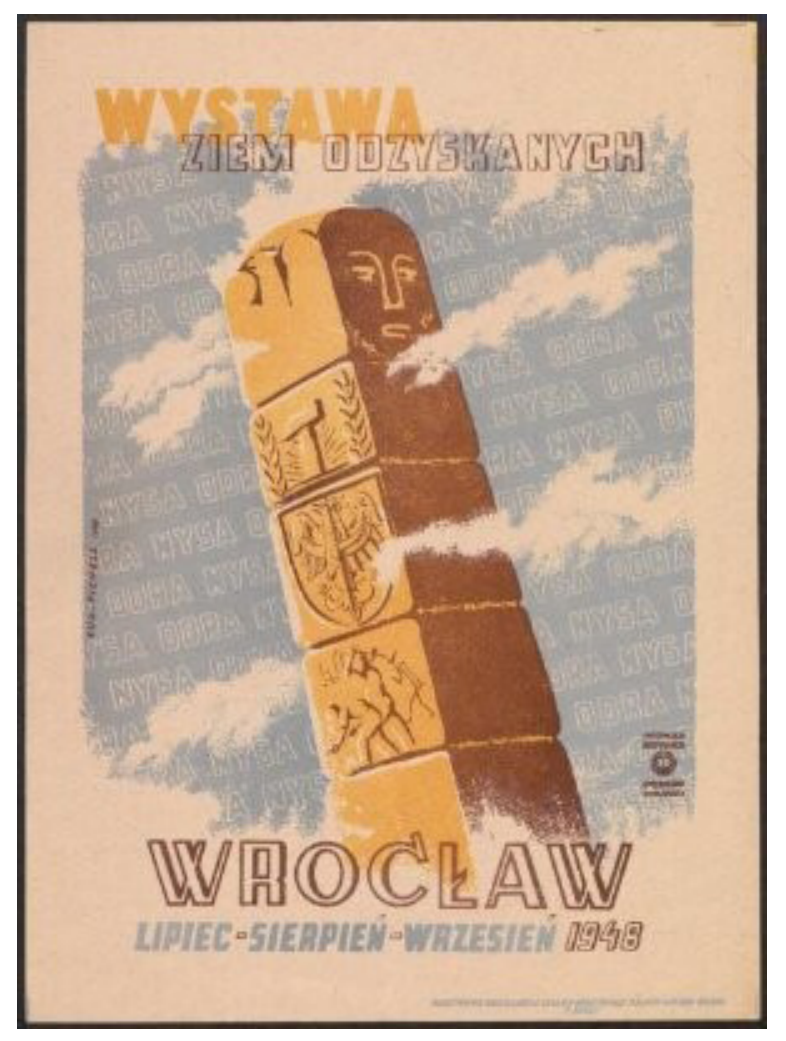

Wystawa Ziem Odzyskanych. This advertisement for the Exhibition of Recovered Territories combines both traditional Polish imagery with communist imagery including the hammer and wheat. Retrieved from Biblioteka Uniwersytecka we Wrocławiu.

\section{Administrative Perspectives}

The Soviets presented Poland with a unique and oftentimes difficult challenge when it came to the incorporation of Wrocław into the Polish state. The city was war torn, but not completely destroyed. It had been German for hundreds of years, and nearly everything in the city including the architecture, infrastructure, and culture reflected German culture. There was a stark difference between the picture of Wrocław that was painted by state propaganda and the city's reality; efforts to incorporate the city were not smooth or well calculated.

Immediately after the war, the Polish government came to realize that they had inherited a very German city that was still stuck in wartime turmoil. The Ministry of the Recovered Territories, headed by PPR ${ }^{32}$ secretary Władysław Gomułka, "oversaw reparation, settlement, local administration, and the incorporation of the territories into Poland." 33 The city was restructured quickly despite the large effort that was required to do so. In 1945, "nowhere was there a feature that one could, without hesitation, recognize as Polish," 34 and "more than 30,000 place names, tens of thousands of natural features... as well as hundreds of thousands of streets and squares were to be given Polish names." ${ }^{35}$ During the time of Soviet occupation, the Red Army had put up signs in Cyrillic script which meant that many streets, landmarks, and buildings already had two names by the time Poland had to rebrand the area, one in German and one in Russian. They now were renamed for the third time in a span of nearly ten years. This caused difficulties in doing repairs, for example, since the administration could not find the correct addresses due to confusion caused by the constant renaming of the same locations. The city's German past permeated it deeply and even made it difficult for the administration to conduct basic operations.

After the rebranding, from 1945-46 the city of Wrocław only had 11 primary schools serving 1250 total students, ${ }^{36}$ one high school serving 908 students, ${ }^{37}$ and one institution of higher learning serving about 2900 students. ${ }^{38}$ Considering 130,000 people

\footnotetext{
${ }^{32}$ Short for Polska Partia Robotnicza (Polish Worker's Party).

${ }^{33}$ Kenney, Rebuilding, 137.

${ }^{34}$ Ibid.

${ }^{35}$ Thum, Uprooted, 244.

${ }^{36}$ Maciaczyk, Statystyka Wroctawia, 57.

${ }^{37}$ Ibid, 61.

${ }^{38} \mathrm{Ibid}, 65$.
} 
arrived in Wrocław in 1946 alone, ${ }^{39}$ it's clear that the education system was insufficient and it is very likely that many children were not going to school. In addition to this, the city's public transportation was in shambles. In 1947, the city only had 151 trams and 5 busses to serve 73.7 million yearly passengers. ${ }^{40}$ The civil administration also had to deal with "buildings and wall fragments continually collapsing, [leftover] mines, unexploded bombshells, munitions depots blowing up," widespread rubble sickness, ${ }^{41}$ and "weapons and ammunition literally [laying] in the streets." ${ }^{42}$ This combined with the "relative lack of trained police" made entire portions of the city uninhabitable. ${ }^{43}$ Neighborhoods in the Western and Southern portions of the city served as "hideouts for entire gangs," 44 looters, and anyone who wanted to remain off the radar. Among other difficulties, the administration was struggling to police the city, educate its residents, and provide them with public transportation.

When presented with this delicate situation, the civil and state administrations floundered. The civil administration was plagued with internal power struggles and inefficiency. The city laid in wait as "no ration cards were issued until November 1945" and "most factories did not begin operation until early 1946." ${ }^{45}$ This standstill left the new inhabitants hungry and out of work in unfamiliar territory. The new communist, government-owned factories promised to house, feed, clothe, and enter-

\footnotetext{
${ }^{39}$ Ibid, 17.

${ }^{40}$ Ibid, 110.

${ }^{41}$ Thum, Uprooted, 177.

42 Ibid, 183.

${ }^{43}$ Kenney, Rebuilding, 141.

44 Thum, Uprooted, 183.

${ }^{45}$ Kenney, Rebuilding, 144.
}

tain their workers ${ }^{46}$ since the betterment of workers was supposed to be the focus of a communist government. These promises were delivered late. The PPR "succumbed to the same bureaucratic temptations as did the other councils and unions," and "activists saw themselves as representatives of party leadership, neither responsive to nor responsible for the local situation." ${ }^{47}$ The administration took no responsibility for what was occurring in the city at the time. Instead, it retreated into bureaucratic entanglements that were only further exacerbated by the situation on the ground.

When later taking action, the administration's choices had a tendency to backfire. As a result of the rapid expulsion of Germans from Wrocław, the city's supply of skilled labor was rapidly depleted. The situation became so dire that the State Ministry of Industry was forced to begin a program of industrial sponsorship where factories in other cities were assigned one in Wrocław and told to populate its labor and administrative core with its own employees. ${ }^{48}$ Factories in other cities responded by sending expendable employees. This led to factories in Wrocław being populated with workers from other cities while locals struggled, and it ensured that the administrative cores of these factories were composed of expendable workers. Those workers were expendable because of their lower quality of work, otherwise they would not have been sent to Wrocław by the factories previously employing them. Placing these workers into positions of authority in factories in Wrocław worsened working conditions.

\footnotetext{
${ }^{46}$ Kenney, Rebuilding, 163.

${ }^{47}$ Ibid, 147.

${ }^{48}$ Ibid, 143.
} 
The one area in which the civil administration excelled was in the production of propaganda. Newspapers loudly proclaimed that bridges were being built on a large scale, ${ }^{49}$ jobs and opportunities were plentiful, and that conditions were ideal. They also "trumpeted Wrocław 'firsts' - first tram line, first newspaper, first cinema," ${ }^{50}$ among other accomplishments. The city of Wrocław had already had all of these things in place when it was still a German city; they were just damaged or destroyed by the war. The communist party wanted to take credit for more than just reconstruction. The administration even spent hundreds of millions of dollars to host an Exhibition of the Recovered Territories in 1948 while the city itself suffered. The administration was intent on painting Wrocław as something it objectively was not. Opinions on Wrocław were "not much higher in Warsaw or Cracow than [they were] in Berlin or Hamburg." ${ }^{51}$ One of the only places Wrockaw was recognized as a robust city rife with opportunity was in the propaganda offices of the civil and state administrations.

The administrative perspectives on the transformation of Breslau into Wrocław tell a story of inefficiency and apathy. The administration failed to provide a basic standard of living for the residents of the city at this time. The city was unsafe due to a lack of policing, its residents were hungry and out of work at times, and there was no initiative to continue the education of the city's populace. In addition, public transportation was in shambles, buildings

\footnotetext{
49 "Budujemy Mosty," Trybuna Robotnicza. July 29, 1946, 205 edition.

${ }^{50}$ Kenney, Rebuilding, 141.

${ }^{51}$ Davies \& Moorhouse, Microcosm, 431.
}

were unsafe to live in, money was spent on propaganda instead of reconstruction efforts, and factories were populated with laborers from other cities. Both the civil and state administrations chose to take a step back and not involve themselves in any meaningful way, and, when they did involve themselves, their actions often led to unintended, negative consequences. The civil and state administrations were indisputably presented with a complex problem to untangle when incorporating Wrocław into the Polish state. The city had been ravaged by war, and it had been a German city for hundreds of years. Furthermore, transitioning a city to fit into a communist blueprint is another challenge that the administrations had to face. The choices made by both the civil and state administrations to deal with the issues presented to them ranged from creating propaganda to inaction.

\section{Connections Between Civilian \& Administrative Perspectives}

The civilian and administrative perspectives on the transformation of Breslau into Wrocław tell two different, yet interconnected stories about how the city transitioned from German to Polish territory. The civilian perspectives tell a tale of hardship and chaos. The administrative perspectives showcase the inefficiency in communist bureaucracy. The two combined and compounded where issues in one segment would further issues forming in the other.

The first connection observable between these two is the civil administration's handsoff approach to policing and maintaining order within the city. This helps to explain the actions of the Poles towards the Ger- 
mans that chose to remain in the city. The merciless killing and mistreatment of Germans by Poles that occurred in this period would not have been a possibility if the civil administration could have upheld the rule of law. The Poles harbored intense feelings of hatred following the war, and they were uncomfortable with their new surroundings. It was an already volatile situation that eventually led to Poles acting out. Failing to properly police the city could have been the result of negligence, a lack of resources, or both. It is highly plausible that in doing nothing, the civil administration encouraged the killings by allowing those that partook in them to walk away unscathed.

The second connection that can be observed is that between crime and the absence of jobs in the city. Wrocław became home to many thieves in this period, and the parts of town that they inhabited were unsafe. The war ended in May of 1945, and the migrants from Eastern Europe began pouring into Wrocław shortly after. Some viewed the city as a source of opportunity and came for that reason, but most were expelled from their homes in the East and relocated to Wrocław by force. Ration cards were not distributed until November of that same year, and factories did not begin production until 1946. There certainly is a possibility that some people came to Wrocław specifically to loot, but, given these circumstances, some people likely turned to crime because there were no other options. People still need to eat, and they need ways to be able to pay for food. Without factories and ration systems in place, these conditions could have contributed to the prevalence of crime in the city. The communist government was expected to care for its citizens and provide them opportunities, and, when it failed to do so in a timely manner, those same citizens likely did what they had to in order to survive, even if it was illegal.

Another connection that can be made when comparing the two perspectives is how the lack of a common identity among the newcomers prompted targeted propaganda from the administration. People arriving in Wrocław came from all kinds of ethnic, regional, and economic backgrounds, and the administration was aware of this fact. The only commonalities many of them shared was the ability to speak Polish and the Catholic religion. In smaller communities and neighborhoods, "the most important institution was the church," 52 but beyond that, the administration likely saw an opportunity to try to foster a new sense of shared national identity though communism. This can explain why propaganda posters depicted traditional Polish symbols together with hammers and sickles and why newspapers constantly boasted about the achievements of the communist government. The goal was to present communism as both a positive influence on the country and as a unifying force for the new inhabitants of Wrocław. The administration likely hoped that civilians would read the headlines, see the posters, and then come to believe that the communist brand they saw could be the new unifying force to alleviate social unrest.

Exploring the connections between the civilian and administrative perspectives of this transformation show that the two were interrelated, and that they tended to follow logical cause and effect patterns. Influenc-

\footnotetext{
${ }^{52}$ Kenney, Rebuilding, 163.
} 
es ran both ways; the chaos and hardship experienced by civilians prompted an opportunistic administration to push propaganda, and the inaction of the administration only furthered the suffering of the inhabitants of the city.

\section{The Lasting Impact, Moving Forward, and Conclusions}

The lasting impact of the transformation of Breslau into Wroclaw affected generations of Poles to come. The remnants of Wrocław's previous German inhabitants constantly surrounded the new inhabitants, and, as decades came to pass, they came to accept them along with the city's history. Olga Tokarczuk captures this experience in her novel House of Day, House of Night. She herself is a Polish woman who ended up moving to and living near Wrocław decades after the war. The novel is a collection of short stories and experiences, and the casual way in which German remnants of the city appear to the characters in the novel reflect the experiences of Poles growing up in or near Wrocław after the war. A young Polish child is casually described as being pushed along a path by his sister in "an old German pram," ${ }^{53}$ discovering a German automobile while exploring in the forest,${ }^{54}$ and playing in "houses that were abandoned by the Germans." ${ }^{\circ 5}$ Additionally, the main character at one point comes to the realization that it was a German family that originally built the house in which she had been living. ${ }^{56}$ People

${ }^{33}$ Olga Tokarczuk, House of Day, House of Night, (Evanston, IL: Northwestern University Press, 2003), 12.

${ }^{54}$ Ibid, 26.

${ }^{55} \mathrm{Ibid}, 18$.

${ }^{56}$ Ibid, 92. growing up in Wrocław after the transition faced similar, repeated occurrences. German lab equipment was still used in schools, abandoned German bunkers became slides for children during the winter, and German greenery was still present throughout the city. ${ }^{57}$ Many of the generations of Poles growing up surrounded by these remnants of German history knew that these buildings and objects were German but never paid them too much mind. ${ }^{58}$

This marks a distinct shift in attitude and a departure from the anti-German bitterness that plagued the initial transformation of Breslau into Wrocław. The postwar generations of Poles who inhabited Wrocław likely felt less of a need for revenge and less of a need to assert themselves than the previous generation because they did not experience the war or any of the atrocities associated with it. It was likely easier for postwar generations to cope due to a lack of firsthand experience. They were able to be indifferent to the material remnants of the city's German past unlike those who experienced the war firsthand. It could be argued, however, that future generations were so indifferent precisely because only material remains were left.

Their indifference could also be explained by the shift of attitudes regarding Wrocław's status as Polish. In the decades following this transition, Poles growing up in or around the city had no reason to believe that the city was not Polish. It was ethnically almost $100 \%$ a Polish city with streets, churches, and parks all rebuilt by Poles. History was erased as the city was in-

\footnotetext{
${ }^{57}$ Conversation with Professor Justyna Beinek. September 25, 2019. Bailey Hall, University of Kansas. ${ }^{58}$ Ibid.
} 
corporated into Poland, and, because of this, people growing up in this environment had no reason to doubt that the city was Polish and that it would remain that way. During the initial transformation of the city, however, the exact opposite attitude was prevalent. Many in 1945-1948 believed that the city would not remain in Polish hands for long, and, as a result of this, the existence of remnants of the previous German inhabitants caused bitterness and anxiety. Future generations of Poles growing up in Wrocław did not have these same anxieties. They were able to take on an attitude of indifference because the Wrocław they knew was definitively Polish, and the material remnants of German inhabitants were viewed as nothing more than fossils.

The transformation of Breslau into Wrocław from 1945-1948 taught the Polish nation a hard lesson about itself, and it can also be used as an example of the complexities in a transfer of sovereignty. Coming out of the war, the common Western and Polish attitudes towards Poland's wartime was one of pity and sorrow. The invasion of Poland had begun the war, the Holocaust took place on Polish soil, uprisings were crushed, and war crimes were committed against the Poles by both Germany and the Soviet Union. After being put through all of this, Poles decided to flip whatever abuse they could back onto the Germans remaining in their new territory. This certainly challenges the idea that Poles were nothing more than victims of the war. It is clear that they were guilty of participating in the same behavior that the Germans were when given the chance, and it is also clear that their acute desire for revenge was a primary consideration during this period of the transformation.

In the short span of three years, the ethnic composition of the city was completely transformed. This alone would have been enough to place any major city into a state of confusion, but when this transition was combined with the traumas associated with the aftermath of the Second World War, the imposition of communism in the city, and an inept civil administration, it unraveled and challenged the city. Poles mistreated, looted from, and killed many Germans that chose to remain in the city. They felt few ties to fellow residents, little connection to their new homes, and little to no sense of belonging in the newly Polish city. They also struggled to feel loyalty to the ineffective communist government that presided over them. Both the civil and state administrations failed to provide a basic standard of living for their people for months at a time which was largely a result of bureaucratic entanglements and mismanagement of time, effort, and money. The problems in administration only served to further the suffering of the civilians, and the chaos of the civilian experience caused the already clumsy administration to focus any constructive efforts on mainly the wrong problems. This resulted in a generally miserable experience for those involved. 


\section{Work Cited}

Primary Sources:

“3,000 Germans Leave Poland for Allied Zones.” Chicago Daily Tribune (1923-1963), Feb 26, 1946.

Balet, Chór, Orkiestra Domu Wojska Polskiego z Warszawy. Photograph. Wrocław, 1948. Retrieved from Biblioteka Uniwersytecka we Wrocławiu.

- Translation: Ballet, Polish Army's Orchestra from Warsaw

"Budujemy Mosty." Trybuna Robotnicza. July 29, 1946, 205 edition.

- Translation: "We are building bridges", Worker's Tribune

Conversation with Professor Justyna Beinek. September 25, 2019. University of Kansas.

Kaps, Johannes. The Tragedy of Silesia 1945-46 ; a Documentary Account with a Special Survey of the Archdiocese of Breslau. Munich: Christ Unterwegs, 1952.

Kapturczak, Henryk. Wspomnienia z Okresu Okupacji. Poznan, 1947. Family Document.

- Translation: Memories from the Period of Occupation [by the Germans]

Leahy, William D. "Notes on the Yalta Conference." The Wisconsin Magazine of History 38, no. 2 (1954): 67-112. Accessed March 5, 2020. www.jstor.org/stable/4632787.

Maciaczyk, Alicja. Statystyka Wrocławia w Latach 1945-1999. Wrocław: Urzad Statystyczny, 2000.

- Translation: Statistics about Wroctaw from 1945 to 1999

Ulotka Propagandowa: Wystawa Ziem Odzyskanych. Photograph. Wrocław, 1948. Retrieved from Biblioteka Uniwersytecka we Wrocławiu.

- Translation: Propaganda Leaflet: Exhibition of Recovered Territories

Wolanowski, L. "Iglica I Dobrzy Restauratorzy." Przekrój Issue 171. Accessed October 22, 2019. https://Przekrój.pl/en/archive/artykuly/7303?f=numer.

- Translation: Spire and good restaurateurs

Zapisy Wojskowe Dziadka \#1. Barc, Alfred, 1945. Family Document.

- Translation: Grandpa's War Notes \#1

Secondary Sources:

“Centennial Hall in Wrocław." UNESCO World Heritage Centre. UNESCO. Accessed October 15, 2019. https://whc.unesco.org/en/list/1165/.

Cienciala, Anna M. "Poles and Jews Under German and Soviet Occupation, September 1, 1939

- June 22 1941.” The Polish Review 46, no. 4 (2001): 391-402. Accessed March 14, 2020. www.jstor.org/stable/25779290.

Davies, Norman, and Roger Moorhouse. Microcosm Portrait of a Central European City. London: Pimlico, 2003.

"Iglica." Visit Wrocław. Oficjalny serwis turystyczny. Accessed October 15, 2019. https:// visitWrocław.eu/miejsce/iglica.

- Translation: "Spire”, Official Office of Tourism 
Kenney, Padraic Jeremiah. Rebuilding Poland Workers and Communists, 1945-1950. Ithaca, NY: Cornell Univ. Press, 2012.

Leahy, William D. "Notes on the Yalta Conference." The Wisconsin Magazine of History 38, no. 2 (1954): 67-112. Accessed March 5, 2020. www.jstor.org/stable/4632787.

Orenstein, Mitchell A. "Poland: From Tragedy to Triumph." Foreign Affairs 93, no. 1 (2014): 2327. Accessed March 14, 2020. www.jstor.org/stable/23526932

"Poland in 1945." United States Holocaust Memorial Museum. United States Holocaust Memorial Museum. Accessed December 12, 2019. https://encyclopedia.ushmm.org/content/en/ article/poland-in-1945.

Talewicz-Kwiatkowska, Joanna. "Persecution and Prejudice Against Roma People in Poland after World War II." The Polish Review 64, no. 2 (2019): 37-45. Accessed March 14, 2020. www.jstor.org/stable/10.5406/polishreview.64.2.0037.

Thum, Gregor. Uprooted: How Breslau Became Wroctaw during the Century of Expulsions. Princeton: Princeton University Press, 2011.

Tokarczuk, Olga. House of Day, House of Night. Evanston, IL: Northwestern University Press, 2003.

Westermayr, Arthur J. “The Psychology of Fear.," The Open Court Vol. 1915, no. 4 (1915): 250255. Accessed March 14, 2020. https://opensiuc.lib.siu.edu/ocj/vol1915/iss4/5 